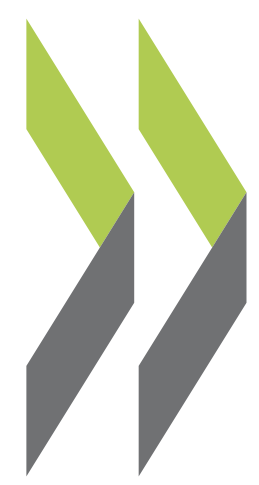

OECD Economics Department Working Papers No. 833

\author{
Improving the Flexibility \\ of the Dutch Housing Market \\ to Enhance Labour Mobility
} Jens Høj 
Organisation de Coopération et de Développement Économiques

Organisation for Economic Co-operation and Development

17-Jan-2011

ECONOMICS DEPARTMENT

English - Or. English

IMPROVING THE FLEXIBILITY OF THE DUTCH HOUSING MARKET

TO ENHANCE LABOUR MOBILITY

ECONOMICS DEPARTMENT WORKING PAPER N 833

By Jens Høj

All Economics Department Working Papers are available through OECD's Internet website at http://www.oecd.org/eco/Workingpapers. 


\section{ABSTRACT / RÉSUMÉ \\ Improving the flexibility of the Dutch housing market to enhance labour mobility}

The housing market figures among the main determinants of labour mobility, as households seldom make employment and housing decisions independently of each other. This interdependence is likely to strengthen as the cost of commuting increases, due to worsening road congestion or measures that would raise fuel prices, for example to counter global warming. The Dutch housing market is more rigid than in many other OECD countries, as the result of numerous government interventions. Boosting labour mobility by easing rigidities would improve labour resource utilisation, which will be especially important as the labour force contracts with ageing. The rental sector could be made more attractive and flexible by dismantling strict rent regulation and rigid allocation mechanisms in the social housing sector. Lowering tax incentives to homeowners would improve the allocation of scarce capital and reduce house prices. Easing strict land-use and zoning regulation would increase the supply of all types of housing, reducing prices and allowing the housing stock to adjust better to residents' needs. This Working Paper relates to the 2010 OECD Economic Survey of the Netherlands (www.oecd.org/eco/surveys/ netherlands).

JEL classification: R23, R3, J61.

Keywords: Housing, labour mobility, social housing, own-occupied housing, rent regulation.

$$
+++
$$

\section{Renforcer la flexibilité du marché immobilier néerlandais pour améliorer la mobilité de la main-d'œuvre}

Le marché immobilier est l'un des principaux déterminants de la mobilité de la main d'œuvre, car les ménages prennent rarement de décisions en matière d'emploi et de logement de façon disjointe. Cette interdépendance est vraisemblablement appelée à se renforcer, par suite de la hausse du coût des migrations pendulaires liée à la congestion du réseau routier ou aux mesures renchérissant l'essence, par exemple dans le cadre de la lutte contre le réchauffement climatique. Le marché immobilier néerlandais est plus rigide que dans de nombreux pays de l'OCDE, par suite des nombreuses interventions du gouvernement. Stimuler la mobilité professionnelle en atténuant ces rigidités permettrait d'optimiser l'utilisation des ressources en main d'œuvre, ce qui serait tout particulièrement important à l'heure où le nombre d'actifs diminue sous l'effet du vieillissement de la population. Le secteur locatif pourrait gagner en attractivité et en souplesse si le strict encadrement des loyers et les mécanismes rigides d'attribution étaient supprimés dans le secteur du logement social. La réduction des aides fiscales accordées aux propriétaires améliorerait l'affectation de ressources limitées et ferait baisser les prix de l'immobilier. L'assouplissement des règles foncières et du zonage entraînerait une hausse de l'offre de logements de tous types, ce qui ferait baisser les prix et permettrait de mieux ajuster le parc immobilier aux besoins de la population. Ce document de travail se rapporte à l'Étude économique des Pays-Bas de 2010 (www.oecd.org/eco/etudes/Pays-Bas).

Classification JEL : R23, R3, J61.

Mots clés: Logement, mobilité de la main-d'œuvre, logement social, logements en accession à la propriété, réglementation des loyers.

Copyright OECD, 2010

Application for permission to reproduce or translate all, or part of, this material should be made to: Head of Publications Service, OECD, 2 rue André Pascal, 75775 Paris Cedex 16, France. 


\section{TABLE OF CONTENTS}

Improving the flexibility of the Dutch housing market to enhance labour mobility ..............................5

Rigidities in the housing market have an impact on labour mobility .........................................................6

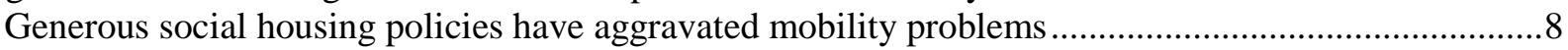

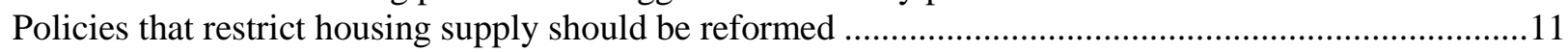

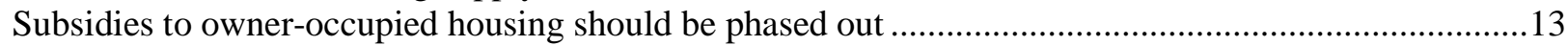

Owner-occupied housing is largely subsidised ……............................................................................13

Subsidisation combined with transfer taxes leads to large welfare losses .............................................14

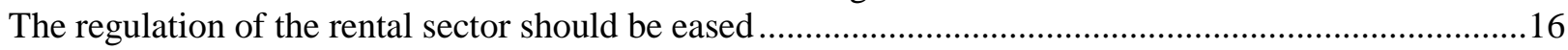

Strict rent regulation does not differentiate between social and private renting .................................16

The substantial subsidisation of rental housing leads to large welfare losses ........................................19

A larger role for the deregulated rental sector to improve labour mobility.........................................20

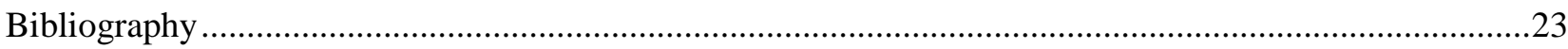

Annex 4.A1 Social housing policies in the Netherlands: a historical perspective.......................................28

\section{Boxes}

1. International evidence on the relationship between housing and labour market mobility ...............5

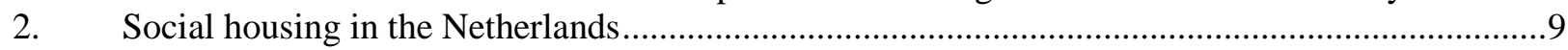

3. Rationale for government intervention in housing markets based on welfare economics ..............11

4. Housing allowances provide for targeted affordability in rented housing ....................................16

5. Recommendations to increase the flexibility in the housing market to enhance labour mobility..22

A1.1. Dutch social landlords and the framework of policy and control ................................................29

\section{Tables}

1. Tenants move less than in other EU countries..............................................................................

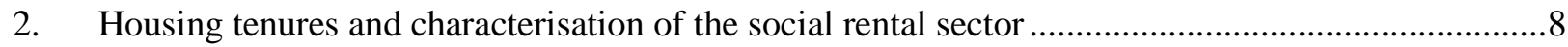

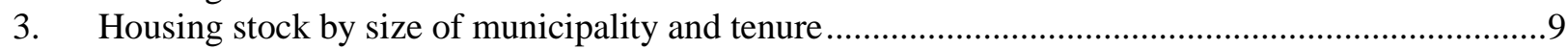

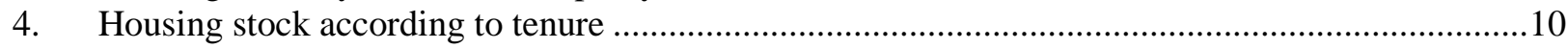

5. Incomes of households in renting and owner-occupation .....................................................11

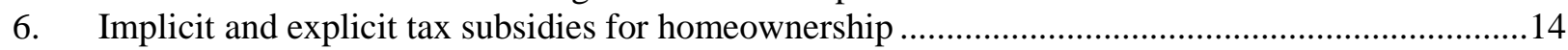

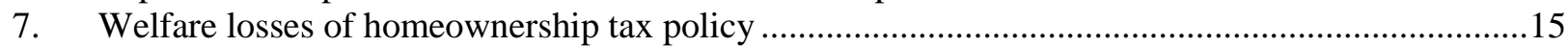

8. Rent regulation in seven European countries ........................................................................18

9. Number of social rental dwellings per rent level as expressed by extent of possible subsidisation via rent allowances ................................................................................................................... 18

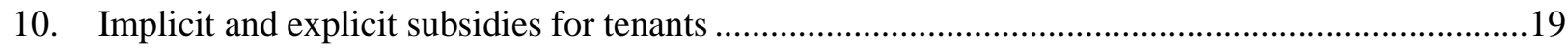

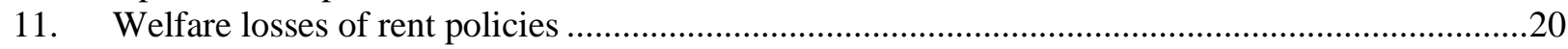

\section{Figures}

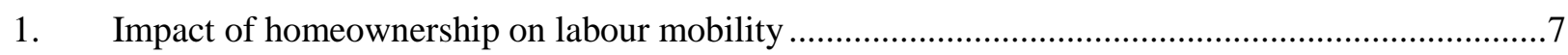

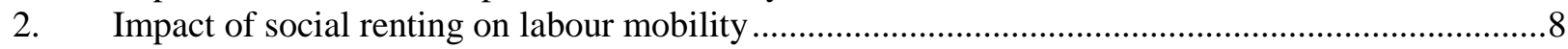

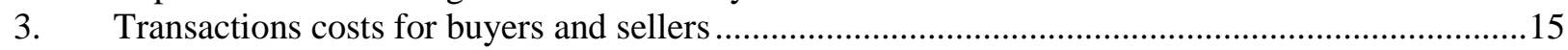


ECO/WKP(2011)2 
ECO/WKP(2011)2

\title{
IMPROVING THE FLEXIBILITY OF THE DUTCH HOUSING MARKET TO ENHANCE LABOUR MOBILITY
}

\author{
By Jens Høj ${ }^{1}$
}

A rigid housing market reduces the labour mobility of households, which weighs on employment rates and could lead to misallocations of labour across regions and sectors, although the empirical evidence on the extent of the link - both internationally and in the Netherlands - between housing and labour market mobility is mixed (Box 1) ${ }^{2}$. The rigidity of the housing market arises from government interventions. In the Netherlands, interventions are typically directed both at home owners (e.g., mortgage interest deductibility; strict zoning regulation) and at renters (e.g., social housing, rent regulation, tax subsidies, etc.). Such implicit and explicit housing subsidies may contribute to disincentives to work as they increase marginal effective tax rates. Furthermore, they may increase the resistance to moving, and thus aggravate any spatial mismatch between the locations of dwellings and jobs. ${ }^{3}$ The paper's first section identifies rigidities in the Dutch housing market that may hinder labour mobility or result in a sub-optimal consumption of housing. The second section analyses which policy instruments should be adjusted to reduce rigidities in the owner-occupied sector. The third section discusses how to improve policy instruments directed at the rental sector. The paper concludes with a set of policy recommendations.

\section{Box 1. International evidence on the relationship between housing and labour market mobility}

There is relatively consistent evidence that tenants in rental dwellings of public authorities, typically social housing (e.g. with below-market rent) will move less (relative to private renting) and are associated with higher local unemployment levels. Early (1980s) evidence on this topic comes from the UK (see overview of De Graaff et al., 2009). More recently Battu et al. (2009) show that unemployed social tenants in the UK are less likely to take a job in a distant labour market than private tenants. Australian research also finds that public tenants who pay below market rents (and those living rent-free) have reduced incentives to move for job reasons (De Graaff et al. (2009) based on Flatau et al., 2003). Danish research also shows that tenancy mobility is reduced by rent regulation (Munch and Svarer, 2002; Svarer et al., 2005).

1. Jens Høj is Head of Belgium and the Netherlands desk in the Economics Department of the OECD. This Working Paper is based on Chapter 4 of the OECD’s 2010 Economic Survey of the Netherlands which was prepared under the responsibility of the Economic and Development Review Committee. The author is grateful for the valuable comments received from Andrew Dean, Bob Ford, Pierre Beynet Tomasz Koźluk and other colleagues in the Economics Department. Special thanks go to Sylvie Foucher-Hantala and Agnès Cavacuitti for statistical assistance and Sylvie Ricordeau for secretarial assistance.

2. Senior Researcher Marietta Haffner from Delft University of Technology contributed research and drafting to Chapter 4.

3. Housing support could indirectly foster employment through better education, although this positive aspect is generally considered as having a smaller impact than the negative aspects. 
Research into the relationship between homeownership and the labour market mobility kicked off later than on the mobility effects of public/social renting, and mainly as a result of the observation of Oswald $(1996,1997,1999)$ that countries with a higher rate of homeownership have a higher rate of unemployment (Green and Hendershott, 2001; Partridge and Rickman, 1997; Pehkohnen, 1999) and that homeowners are unemployed more often than tenants. On the other hand, tenants have lower employment rates (Dohmen, 2009). Micro-level evidence which is well suited to control for the characteristics of households, suggests somewhat different results. Homeowners tend to become unemployed less often and tend to leave unemployment earlier (Van Ewijk and Van Leuvensteijn, 2009). Evidence from Australia shows that highly leveraged owners having a greater incentive to stay employed and search hard to become re-employed quickly after job loss (Flatau et al., 2003).

Dutch research results are somewhat conflicting. Micro-economic research suggests that homeowners may or may not be more mobile when a next job is at stake, while generally they tend to be unemployed less often and tend to have shorter spells of unemployment (Van Leuvensteijn and Koning, 2000, 2009; Van der Vlist, 2001; Van Vuuren, 2009). On the other hand, homeowners are generally more likely to find a job in the local labour market and less likely to find one in the distant labour market (Van Vuuren, 2009), although Van Leuvensteijn and Koning (2009) find no impact of homeownership on job mobility, perhaps reflecting the fact that the Netherlands is a relatively small country.

\section{Rigidities in the housing market have an impact on labour mobility}

Overall household mobility is about average compared with other European countries, but well below that in the high mobility countries (Table 1). Relatively low mobility is particularly marked in the social rental sector. In most countries the flexible segment of the housing market is usually the rental sector, particularly the private rental sector, but this has been sharply declining, and is now quite small, segment of the Dutch housing market. Thus, low mobility in these areas should be worrisome in the context of labour mobility.

Table 1. Tenants move less than in other EU countries

Percentage of households that moved residence in the year prior to the interview, 1994-2001

\begin{tabular}{lcccc}
\hline & Total & Owner-occupier & $\begin{array}{c}\text { Social rental } \\
\text { tenant }\end{array}$ & $\begin{array}{c}\text { Private rental } \\
\text { tenant }\end{array}$ \\
\hline Ireland & 2 & 1 & 3 & 26 \\
Austria & 3 & 1 & 4 & 8 \\
Greece & 3 & 2 & 9 & 10 \\
Italy & 3 & 2 & 2 & 8 \\
Portugal & 4 & 3 & 5 & 6 \\
Spain & 4 & 3 & 6 & 12 \\
Netherlands & 5 & 5 & 6 & 12 \\
Belgium & 6 & 3 & 9 & 16 \\
Sweden & 6 & 3 & $\mathrm{n} . \mathrm{a}$. & $\mathrm{n} . \mathrm{a}$. \\
Luxembourg & 6 & 4 & 8 & 12 \\
Germany & 7 & 3 & 7 & 11 \\
France & 8 & 4 & 10 & 21 \\
United Kingdom & 8 & 6 & 9 & 36 \\
Denmark & 10 & 6 & 15 & 26 \\
Finland & 10 & 5 & 25 & 34 \\
Average & 6 & 3 & 8 & 17 \\
\hline
\end{tabular}

n. a.: not available.

Source: De Graaff et al. (2009; see also Van Ommeren, 2006) based on analyses with the European Community Household Panel 1994-2001. 
Labour mobility is, nonetheless, not particularly low in the Netherlands compared with other countries. Based on statistics from the European Foundation for the Improvement of Living and Working Conditions (2005), job mobility in the previous year (as well as over the past 5 and 10 years) scores slightly above the EU-25 average. The Netherlands also has a lower share of people who have never changed employers (16\% compared to $24 \%$ in the EU-25 average) and, as a result, lower than average job duration (about 7 years). However, these results are more linked to the organisation of the labour market. Indeed, empirical evidence shows that the Dutch move between areas because of changes in housing supply and not because of new employment opportunities, emphasising the effects of a rigid housing supply (Vermeulen and Van Ommeren, 2006). Survey evidence indicates that less than 5\% of households moved for employment reasons (RIGO Research en Advies BV, 2007). This may reflect that commuting is relatively easy, as most of economic activity is concentrated in the rather small Randstad area, encompassing Amsterdam, Utrecht, Rotterdam and The Hague. But the choice of commuting may also reflect housing rigidities. Housing rigidities may then hinder job mobility and/or increase the social cost of commuting (OECD, 2010).

Homeowners in EU countries have on average a smaller probability of moving between dwellings than tenants in private rentals, and they also have a smaller probability of becoming unemployed (De Graaff et al. 2007). However, there is considerable country-specific variation. The Netherlands stands out with a relatively large negative impact of homeownership on job-to-job mobility and unemployment (Figure 1).

\section{Figure 1. Impact of homeownership on labour mobility ${ }^{1}$}

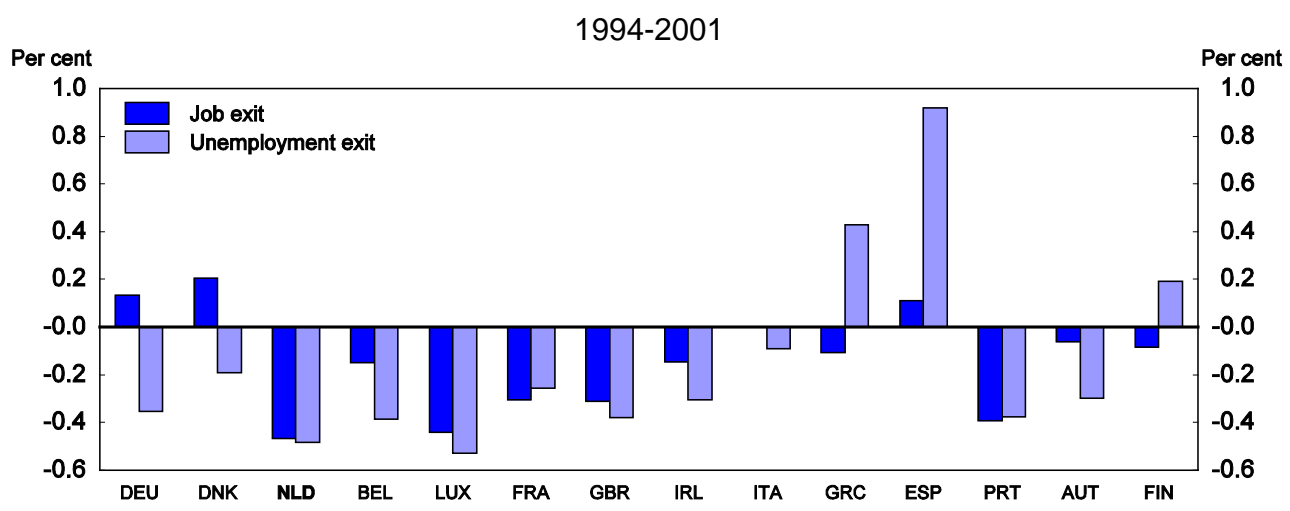

1. The figure shows the impact that homeownership has in comparison with private renting on the probability of leaving the current job for another job or leaving the current job for unemployment.

Source: De Graaff, Thomas, Michiel van Leuvensteijn and Casper van Ewijk (2009), Homeownership, Social Renting, and Labour Mobility across Europe, in: Van Ewijk, Casper and Michiel Van Leuvensteijn (2009) Homeownership and the Labour Market in Europe, Oxford, Oxford University Press.

The same study found that, within the EU countries, tenants in social housing have on average higher job-to-job mobility than tenants in private rentals, but a higher risk of becoming unemployed. However, it is the opposite in the Netherlands. Tenants in social housing have lower job-to-job mobility and a lower risk of becoming unemployed than tenants in private rentals (Figure 2) which may be linked to the potential loss of the implicit subsidy provided to high income tenants (see below). It should be noted, though, that Dutch social housing associations (the organisations that own and manage social housing) tend to serve a more heterogeneous group than in other countries, implying that differences in tenant characteristics could be behind this outcome. 
Figure 2. Impact of social renting on labour mobility ${ }^{1}$

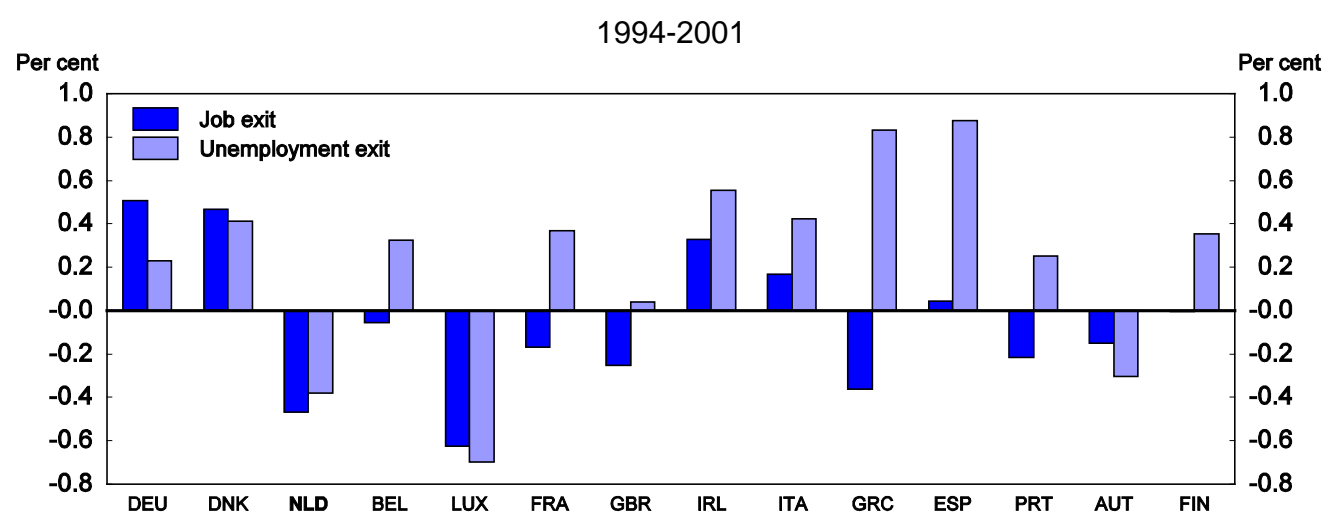

1. The figure shows the impact that social renting has in comparison with private renting on the probability of leaving the current job for another job or leaving the current job for unemployment.

Source: De Graaff, Thomas, Michiel van Leuvensteijn and Casper van Ewijk (2009), Homeownership, Social Renting, and Labour Mobility across Europe, in: Van Ewijk, Casper and Michiel Van Leuvensteijn (2009) Homeownership and the Labour Market in Europe, Oxford, Oxford University Press.

\section{Generous social housing policies have aggravated mobility problems}

The Netherlands has the largest social rental sector in the EU, and rent regulation ensures rents well below market value (Table 2) (Box 2). Not only does this create queues, but it also gives strong incentives to tenants not to adjust their housing demand in line with changing circumstances on the labour market or with changing family situations. In particular, tenants wishing to move within the social housing segment may have to enter a new rental contract, which generally has higher rents (partly related to quality differences), or may even no longer be qualified for social housing because their incomes have risen (higher income does not disqualify those already in social housing). Mobility may be further hampered due to the creation of income traps via the interaction between housing allowances and other income support.

Table 2. Housing tenures and characterisation of the social rental sector in the EU

EU-27 countries with the largest market shares of the social rental sector, 2007

\begin{tabular}{|c|c|c|c|c|c|c|c|c|}
\hline Country & $\begin{array}{c}\text { Owner } \\
\text { occupation } \\
(\%)\end{array}$ & $\begin{array}{c}\text { Private } \\
\text { rented } \\
(\%)\end{array}$ & $\begin{array}{l}\text { Other } \\
(\%)\end{array}$ & $\begin{array}{c}\text { Social } \\
\text { rented } \\
(\%)\end{array}$ & $\begin{array}{l}\text { Per } 1000 \\
\text { inhabitants }\end{array}$ & $\begin{array}{l}\% \text { of } \\
\text { rented } \\
\text { stock }\end{array}$ & $\begin{array}{c}\text { New } \\
\text { construction }\end{array}$ & $\begin{array}{c}\% \text { of } \\
\text { housing } \\
\text { construction }\end{array}$ \\
\hline Netherlands & 54 & 11 & 0 & 35 & $147^{1}$ & 77 & $25200^{1}$ & $32^{1}$ \\
\hline Austria & 58 & 19 & 2 & 21 & 102 & 53 & 14500 & 35 \\
\hline Denmark & 53 & 26 & 1 & 20 & 102 & 43 & n. a. & 21 \\
\hline Sweden & 54 & 22 & 3 & 21 & 95 & 48 & 6000 & 20 \\
\hline United Kingdom & 69 & 10 & 0 & 21 & 85 & 68 & n. a. & 11 \\
\hline Czech Republic & 66 & 12 & 1 & 20 & 85 & 61 & 5000 & 20 \\
\hline France & 56 & 25 & 0 & 19 & 71 & 43 & n. a. & 9 \\
\hline Finland & 63 & 16 & 3 & 18 & 74 & 52 & 4000 & 12 \\
\hline Poland & 75 & 13 & 0 & 12 & 39 & 47 & n. a. & 8 \\
\hline Ireland & 79 & 13 & 0 & 9 & 29 & 38 & 5127 & 6 \\
\hline
\end{tabular}

n. a.: not available.

Source: Czischke and Pittini (2007). Centraal Fonds Volkshuisvesting (2009); CBS (2007); Housing Statistics in the European Union 2005/2006. 


\section{Box 4.2. Social housing in the Netherlands}

The large social rental sector is the outcome of continuous government intervention since the 1901 Housing Act (Haffner et al., 2009a). In the beginning of the 1990s, social housing policies changed to become geared towards decentralisation, deregulation and (financial) independence, including securing their investment risk capacity and giving greater freedom in rent setting and asset management. Moreover, social landlords became financial independent institutions with public task via a grossing and balancing operation in 1995, when the government paid off the net present value of its annual subsidy obligations to the social landlords and the social landlords (mainly) reimbursed outstanding government loans by means of accelerated repayment, allowing social landlords to operate as (large) revolving funds subsidising social rents themselves (see also Annex A1).

The core mission of the social housing associations is to provide housing for households that are unable to find an appropriate dwelling for themselves (the target group for social renting). Furthermore, the associations have to maintain a decent quality of the dwellings, to consult with the tenants, to be a financially sound organisation, to contribute to livable neighbourhoods (added in 1997) and to provide housing for the elderly and for handicapped people (added in 2001). To finance these tasks, the associations are allowed to generate income from market activities, such as (commercial) renting to non-target groups, developing owner-occupier dwellings for sale, and constructing so-called societal real estate (schools, neighbourhood centres, etc.) (Ministerie van VROM, 2009). In addition, they can raise working capital from the sales of dwellings (Centraal Fonds Volkshuisvesting, 2009).

There are about 400 non-profit housing associations, which have boards of directors as their main decision makers. (Centraal Fonds Volkshuisvesting, 2008). Most of the housing associations are relatively large (and growing) with an average size in urban areas of 9600 dwellings/housing association and 3600 in non-urban areas. The 2007 average market value of the housing associations' rental dwellings was estimated to be EUR 150000 which is considerably larger than the present day value of rents (EUR 34000 ), raising the issue of whether housing associations are efficient instruments to provide social housing (Centraal Fonds Volkshuisvesting, 2008). The total property value of the housing associations is estimated to amount to EUR 380 billion, close to 65\% of GDP.

A main political concern is the ownership of the private housing associations which have no shareholders, questioning how the associations fulfill their public tasks in the absence of strong supervision. In response to these discussions, new tasks and the levying of corporate tax on social landlords (since 2008) have been introduced. Moreover, housing associations have to part-finance and make performance agreements with municipalities for the tackling of 40 problem neighbourhoods as well as reaching agreements with the government on improving energy efficiency of dwellings and increasing the number of affordable homes.

Rental (and particularly social) housing is more predominant in larger cities (Table 3). For example, in the largest metropolitan area the rental sector covers two-third of all dwellings, of which nearly three quarters are social (AFSW, 2007). The large social housing sector appears to have emerged partly at the cost of a shrinking private rental sector (Table 4). In terms of construction activity, social housing is also more active than in other countries, although overall construction activity is not particularly high (Table 2).

Table 3. Housing stock by size of municipality and tenure 2006

\begin{tabular}{lcccc}
\hline Size of municipality & Owner-occupier & Social rented & Market rented & Total \\
\hline Less than 20 000 inhabitants & 70 & 24 & 6 & 100 \\
$20000-50000$ inhabitants & 64 & 29 & 6 & 100 \\
$50000-150000$ inhabitants & 53 & 38 & 9 & 100 \\
More than 150 000 inhabitants & 38 & 47 & 15 & 100 \\
\hline
\end{tabular}

Source: WoON 2006 database (TU Delft calculations). 
Table 4. Housing stock according to tenure

\begin{tabular}{rcccc}
\hline Year & $\begin{array}{c}\text { Owner-occupier } \\
(\%)\end{array}$ & $\begin{array}{c}\text { Social rented } \\
(\%)\end{array}$ & $\begin{array}{c}\text { Market rented } \\
(\%)\end{array}$ & $\begin{array}{c}\text { Total } \\
\text { (thousands) }\end{array}$ \\
\hline 1947 & 28 & 12 & 60 & 2117 \\
1956 & 29 & 24 & 47 & 2547 \\
1967 & 32 & 35 & 33 & 3450 \\
1971 & 35 & 37 & 28 & 3729 \\
1975 & 39 & 41 & 20 & 4281 \\
1981 & 42 & 39 & 19 & 4957 \\
1985 & 43 & 41 & 16 & 5384 \\
1989 & 45 & 41 & 14 & 5802 \\
1995 & 48 & 39 & 13 & 6192 \\
2000 & 51 & 36 & 13 & 6590 \\
2005 & 55 & 34 & 11 & 6859 \\
2006 & 56 & 33 & 11 & 6914 \\
\hline
\end{tabular}

Source: Haffner, M., J. Hoekstra, M. Oxley and H. van der Heijden (2009a), Bridging the gap between market and social rented housing in six European countries, Amsterdam, IOS Press BV.

An instrument to control access to social housing is the designation of the potential policy target group for social housing, based on income and wealth. This group increased between 2001 and 2006 to encompass $68 \%$ of all tenants and $31 \%$ of all owner-occupiers - or almost half of all households (Table 5). ${ }^{4}$ This increase suggests a slow process of widening income differential between owner-occupiers and tenants, so by 2006 the average disposable household income of tenants was less than $60 \%$ of that of owner-occupiers. The potential policy target groups are, in principle, eligible for social rental dwellings (Haffner et al., 2009a; Van Daalen and Van der Land, 2008). Access is often controlled through queuing (sometimes through a lottery for eligible candidates) and where income eligibility is checked upon entry, but not subsequently. Municipalities have a right to determine the rules for allocation, while social landlords allocate the dwellings usually based on a so-called choice-based letting system which requires candidates to make applications for vacant dwellings to allow candidates to choose from available dwellings rather than being just allocated a dwelling. ${ }^{5}$ The most common criteria for allocation of dwellings are then waiting time and length of residence in the present dwelling.

Housing policy has resulted in a much larger social rental sector than in other countries. In a rich country with fairly low inequality, like the Netherlands, this seems to stretch the application of the term "social". As a result, housing consumption choices of households are distorted. Politically, it has proven very difficult to reform housing policies, often leading to reform proposals aiming at individual elements of housing policies rather than wholesale reform. Such piecemeal reforms tend be easily opposed by a relatively small group of potential losers, which is not countered by the creation of a clearly defined group of winners as the benefits tend to be diffused and only materialise over the longer term (Høj et al., 2006; Tompson, 2009). The previous government did not include reform of housing markets as such in its coalition programme, but focussed on tackling the restructuring of 40 so-called problem neighbourhoods (Tweede Kamerfracties CDA, PvdA and ChristenUnie, 2007). One of the 20 committees recently

4. Since then the target group has decreased to $43 \%$ as the income limit has not been indexed with inflation (Ministerie van VROM, 2009). Moreover, the Dutch ministry responsible for housing and the EC Directorate on Competition have agreed that if social landlords allocate at least $90 \%$ of the dwellings to the target group, then all of the social landlords' dwelling is considered to be offered on a level playing field.

5. Some municipalities experiment with the allocation rules to keep low-income tenants from certain housing complexes in order 'to improve' the income mix in the neighbourhood (Wet Bijzondere maatregelen grootstedelijke problematiek). 
established by the government to make spending cut proposals deals with housing policies (see also OECD, 2010).

Table 5. Incomes of households in renting and owner-occupation ${ }^{1}$

\begin{tabular}{|c|c|c|c|c|}
\hline & \multicolumn{2}{|c|}{ Renting } & \multicolumn{2}{|c|}{ Owner-occupation } \\
\hline & 2002 & 2006 & 2002 & 2006 \\
\hline Target group ${ }^{2}$ for housing allowances & $39 \%$ & $44 \%$ & $10 \%$ & $12 \%$ \\
\hline $\begin{array}{l}\text { Remainder of target group }{ }^{3} \text { for social } \\
\text { renting }\end{array}$ & $24 \%$ & $24 \%$ & $18 \%$ & $19 \%$ \\
\hline High-income group & $36 \%$ & $32 \%$ & $72 \%$ & $68 \%$ \\
\hline Total & $100 \%$ & $100 \%$ & $100 \%$ & $100 \%$ \\
\hline \multicolumn{5}{|l|}{$\begin{array}{l}\text { Average disposable household income } \\
\text { per year (EUR) })^{3,4}\end{array}$} \\
\hline Target group ${ }^{3}$ for housing allowances & 12500 & 13300 & 15200 & 17600 \\
\hline $\begin{array}{l}\text { Remainder of target group }{ }^{3} \text { for social } \\
\text { renting }\end{array}$ & 17800 & 18600 & 21700 & 23500 \\
\hline High-income group & 32500 & 32300 & 43400 & 44000 \\
\hline Total & 21100 & 20600 & 36700 & 36800 \\
\hline
\end{tabular}

1. Over $\mathbf{3 0 0} 000$ households not in independent homes are not included in the analysis.

2. A target group contains the households according to income that in principle are eligible for either housing allowances (lower income limit) or social housing (higher income limit). In the rental sector more than 2 million households belonged to this target group in 2006.

3. Disposable household income excludes any income items related to housing such as tax deductions for homeowners and housing allowances.

4. Gross minimum wage was EUR 1284.60 per month as of 1 July 2006. It amounts to a little more than EUR 15400 per year. In net terms, this corresponds to EUR 13100 per year, which is about equivalent to the disposable income of the target group for housing allowances in the rental sector.

Source: Haffner and Boumeester (2009) based on WBO 2002 (revised) and WoON 2006 (TU Delft calculations).

\section{Policies that restrict housing supply should be reformed}

The housing sector has long been shaped by intensive government intervention in the areas of housing, urban renewal and physical planning. Rationales for such intervention can be based on welfare economics (Box 3). The Dutch government interventions had two main consequences: a surprisingly small supply of houses for such a high income country and, partly related, the development of a large social renting sector (ECB, 2009; Tompson, 2009).

\section{Box 3. Rationale for government intervention in housing markets based on welfare economics}

A rationale for government intervention can be provided in the presence of externalities that cannot be internalised in private contracts or local government policy (Teulings et al., 2003; as elaborated by Besseling et al., 2008). These could include the positive and negative (social) external effects of urbanisation, of space and nature as public goods, of liveable neighbourhoods as public goods, of housing key workers, of market power (imperfect competition) of owners of land and dwellings and of income or ethnic segregation. Furthermore, there may be scale advantages achieved through coordination of new construction, renovation and urban renewal which the market by itself may not provide; and there may be situations of imperfect or asymmetric information, e.g. about housing quality or the 'good' tenant. Also distributional considerations may warrant government interventions such as housing allowances. In this respect, government intervention, such as taxes and regulation of land use, quality and protection of recreational areas, etc., will make housing unaffordable for some lower income households. This point to the importance of evaluating whether a specific government intervention has benefits that exceed costs. 
On the supply side, availability in terms of dwellings per inhabitant is 422 dwellings (of relatively good quality) per 1000 inhabitants, which is in the middle range of EU countries. Strict land use policy has contributed to the relatively price inelastic supply of new dwellings in both the short and long-run as compared with other countries (Vermeulen and Rouwendal, 2007; Swank et al., 2002; André, 2009). Some measures have been taken to relax land use policies (the Vinex-directive from the mid-2000s and the new Law on spatial planning (WRo, 2008)) to expand land for constructible use, particularly in areas just outside city boundaries. ${ }^{6}$ In addition, development time for new property has almost doubled since the 1990s to 94 months in 2008 (Eichholtz et al., 2008). Moreover, there is a perceived shortage of housing, which public policies have tried to address. The quantification of the perceived shortage is based on stated preferences of households and demographic development (Besseling et al., 2008). In 1995, the government entered construction agreements with urban regions with the aim of adding 650000 dwellings to the housing stock between 1995 and 2004. Despite achieving the target, a new target of reducing the housing shortage to $1.5 \%$ by 2009 was set (Ministerie van VROM, 2004, 2005). Agreements were again reached with the urban regions on output targets. The social housing landlords were allocated a crucial role in meeting these targets, as they were to produce more than $25 \%$ of the output deemed necessary.

Land use planning is a top down process whereby policy targets are prescribed by central government and provinces and municipalities are in charge of implementation. Traditionally, municipalities finance infrastructure and social projects from revenues from the sale of land, the price of which includes scarcity premiums. More recently, the rules have been relaxed a little, as municipalities in rural areas are now allowed to build for their natural population growth (Ministeries van VROM, LNV, VenW en EZ, 2004). In general, municipalities are free to develop their own regulations, but these must comply with the spatial policies of central and provincial governments as well as national and EU regulations concerning issues such as noise pollution and safety. The relatively strict rules about the location of new construction have traditionally found their roots in arguments for the preservation of open space in the form of nature and agriculture, particularly the so-called Green Heart in the midst of the Randstad area. As the boundaries of the Green Heart have changed little in the past 50 years, even as the population of the Randstad has grown, they are in effect more restrictive nowadays than in the past.

Restrictive land use policy is estimated to add one third to house prices (Besseling et al., 2008). Insiders gain from higher property values while outsiders pay for them via foregone housing consumption. It is estimated that these higher prices amount to about a 10\% consumption tax. Net welfare losses in terms of foregone consumer surplus on the housing market are estimated at EUR 3 billion (0.6\% of GDP) per year. In addition, it is difficult to estimate welfare losses because of the fact that physical planning regulations also prevent the reaping of agglomeration benefits from further growth of cities and indirectly depress labour supply. Van Oort et al. (2008) find that the Randstad area (especially Amsterdam and Utrecht) is a location where employment follows housing, while the present policy for housing construction is not following local economic policy: employment is growing faster than housing supply. Thus, more care should be taken in gearing housing construction to economic and labour market policies in local markets in the Randstad in order not to hamper economic development.

Land use policies may help to preserve living environments in the second most densely populated country in the EU (after Malta). A full evaluation of the cost of land use policies would have to include the associated gains, such as in terms of environment and open spaces (Besseling et al., 2008). Nevertheless, land use policy has led to a situation where $70 \%$ of the Randstad area is devoted to water management and agriculture (OECD, 2007). Thus, a first step would be to subject land use to a full evaluation to inform the

6. Complex and time consuming building regulations will also contribute to supply inelasticity. As of 2010 the cumbersome building and environmental regulations will become less cumbersome and time consuming (Wet Algemene bepalingen omgevingsrecht) as a one permit for the built environment merges about 25 rules and regulations for building, environment, nature, and monuments. 
debate on policy options (Van Hoek, 2009). Indeed, the effective restrictiveness of the zoning laws has increased over time, particularly in the Green Heart, as cities have expanded. Moreover, economic activity is being increasingly concentrated in the Randstad, pointing to further increases in competing demands on land use (OECD, 2010). To assure balanced development, particularly of the 'Green Heart', more housing would be necessary as well as new forests and nature parks. Thus, there is a need for easing zoning laws- a recommendation that already has appeared in previous Surveys. Planning, however, cannot be a standalone measure, so to create incentives for local municipalities to develop housing, they should benefit from such developments, for example in terms of greater (property) net tax revenues.

\section{Subsidies to owner-occupied housing should be phased out}

Transaction taxes increase the cost for home-owners to adjust to changes in their housing demand. Moreover, while the relatively high income tax subsidies to homeowners (arising from generous mortgage interest deductibility and low taxation of imputed rents) affect tenure choice, without a direct impact on household mobility, they may lead to suboptimal housing consumption decisions and hence have more indirect negative effects on mobility.

\section{Owner-occupied housing is largely subsidised}

Tax neutrality from the point of view of individual investors can be achieved if financial and real assets (including housing) are treated as investment goods in the personal income tax system. Since the 2001 tax reform, this principle has been applied for real and financial (non-business) assets in a special way. For tax purposes income from these assets is set at $4 \%$ of net wealth, irrespective of the actual income received (in the form of rent, interest, dividend, etc.) and is taxed at a standard rate of $30 \%$, implying an effective tax rate of $1.2 \%$ on net wealth. The argument for introducing this system was to achieve sustainable (i.e. stable) tax revenues, but at the cost of no longer taxing realised income, contrary to the practice in most other OECD countries.

The exception in the system is the tax treatment of owner-occupied housing. Taxation is based on imputed rent, calculated as less than $1 \%$ of the property value, and mortgage interest payments are fully deductible at the highest marginal tax rates. Typically, the deduction of mortgage interest exceeds the amount of imputed rent. In comparison, owners of other real and financial assets pay tax on their return with no deduction of actual costs (OECD, 2004), leaving housing relatively lightly taxes, or effectively subsidised. ${ }^{7}$ Tax neutrality would require taxing all actual income from financial assets and all imputed income from owner-occupied housing (based on market rates) at the same rate, while allowing deduction of all costs involved in producing that income at the same tax rate. This implies - in the present tax system - a $30 \%$ tax rate on imputed rent, which should be based on $4 \%$ of the value of the house, and that the tax deductibility of mortgage interest payments should be preserved. Even then, there would still be an incentive for households to rely on mortgage loan financing rather than savings as long as the mortgage interest rates are above $4 \%$. Financing neutrality between borrowed and saved money requires that the net value of owner-occupied housing is taxed, i.e. that the tax deductibility of mortgage interest payments is replaced by system where the above tax parameters are applied to the net value of the house (by deducting the mortgage loan from the value of the house).

There are two other subsidisation elements for homeownership. First, there is an income tax exemption of the interest earned on an amount saved (in a special scheme) for the repayment of so-called endowment mortgage loans (up to a certain amount depending on the years saved). Such loans were

7. Owner-occupied housing is more subsidised in the personal income tax system than rental housing and financial assets. In addition to the lack of tax neutrality of different investment vehicles, the tax system also lacks tenure neutrality since the tax favouring of owner-occupied housing over renting biases tenure choices. 
designed to allow homeowners to take advantage of the full mortgage interest deduction. The effect is to allow deduction of interest on the full (initial) value of the mortgage while, in effect, paying down the principal. ${ }^{8}$ Secondly, homeowners that have repaid their mortgages are no longer subject to the tax on imputed rent. There have been some measures to reduce the tax subsidy to owner-occupation, notably a 2001 limitation of deductions to 30 years and to the principal dwelling, and in 2004 the deductibility for second-time buyers was limited to a loan that is equal to the difference between the value of the new dwelling and the accumulated equity in the previous dwelling.

Overall, the estimated budgetary cost of the subsidisation of owner-occupied housing amounts to 2.6\% of GDP (Table 6). This amount implies a first-round subsidy to housing of more than EUR 3000 per owner-occupied household per year, which is equal to a subsidy of about one fifth of housing costs. All in all, the income tax position for owner-occupied housing results in a more favourable treatment of owneroccupiers in comparison with private landlords and in comparison with financial assets and pushes up house prices by $10 \%$ to $30 \%$ (Conijn, 2008).

Table 6. Implicit and explicit tax subsidies for homeownership

\begin{tabular}{lccc}
\multicolumn{2}{c}{2006} & \\
\multicolumn{1}{c}{ Type of subsidy } & $\begin{array}{c}\text { Total in EUR } \\
\text { billion }\end{array}$ & $\begin{array}{c}\text { Average per household } \\
\text { (EUR) }\end{array}$ & $\begin{array}{c}\text { Average per } \\
\text { household }\end{array}$ \\
\hline Mortgage interest deduction
\end{tabular}

1. Percentage of housing costs (expressed as a percentage of imputed market rental income).

2. Including exemption of capital insurance policy and the deduction of mortgage costs.

Source: Besseling P., L. Bovenberg, G. Romijn and W. Vermeulen (2008; based on Koning et al. 2006).

\section{Subsidisation combined with transfer taxes leads to large welfare losses}

For owner-occupied housing, while ownership is subsidised, purchasing is taxed. Transaction taxes are $6 \%$ of the acquisition price in the Netherlands, which amounts to a bit more than half of the total cost of moving (Figure 3). Although the latter is about average in a European context, the cost of moving is still associated with substantial welfare costs. In particular, economic studies show that transaction costs result in lock-in effects to a larger extent than taxation of ownership. This leads to suboptimal consumption decisions, implying that the welfare loss associated with transaction taxes is much higher than that of taxation of ownership (Van Ommeren and Van Leuvensteijn, 2003; Rouwendal and Van Ommeren, 2006; O'Sullivan et al., 1995). The empirical evidence suggests, as in other countries, that a one percentage point decrease in the value of transactions costs increases ownership-to-ownership mobility rates by 8\% (Van Ommeren and Van Leuvensteijn, 2003, 2005; Rouwendal and Van Ommeren, 2006). Moreover, the lock-

8. In practise, mortgage payments go into a savings account and these accumulated savings are used to repay the full mortgage loan on the day it expires and the tax advantage takes the form of the non-taxation of interest earned on the amount saved. 
in effects are pro-cyclical (inversely related to vacancy rates), implying that mobility is reduced when faster reallocation of labour is needed to sustain such upswings (Lundborg and Skedinger, 1999).

Figure 3. Transactions costs for buyers and sellers

$\%$

As a percentage of property value in 2007

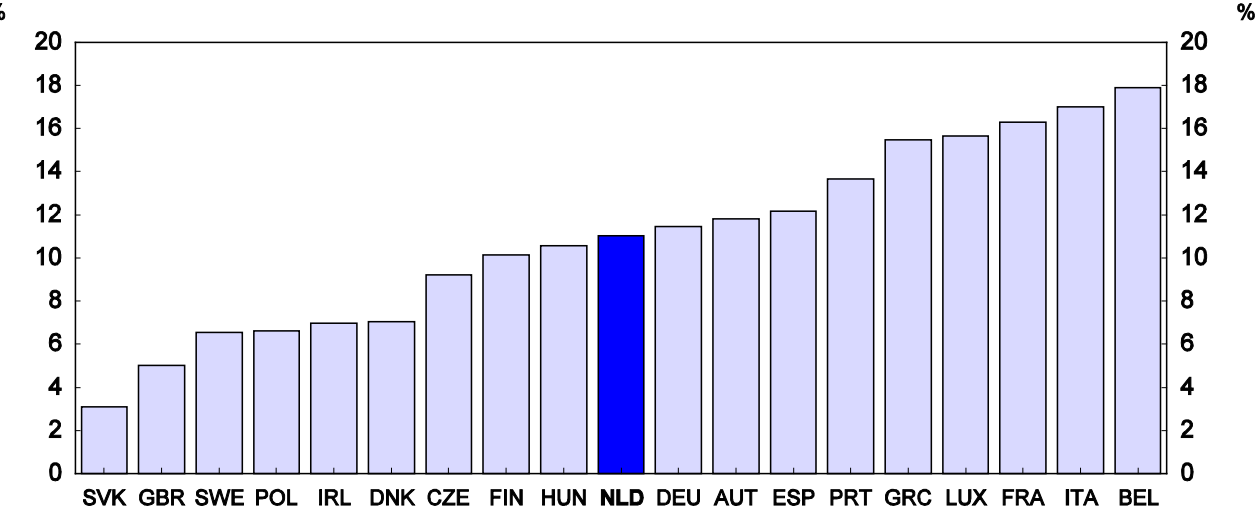

Source: De Montfort University calculations based on Global Property Guide - last updated 15.10.2007, Roundtrip Transaction Costs as a percentage of property value.

The transfer tax and the income tax subsidisation of owner-occupied also lead to welfare losses of at least EUR 1.5 billion per year (0.3\% of GDP) assuming a relatively high long-term price elasticity in supply (and $0.2 \%$ of GDP if a zero elasticity is assumed) (Table 7). The largest part is attributable to the direct effects of the transfer tax, followed by the losses as a result of biasing the tenure choice between owning and renting (the lack of tenure neutrality). The smaller welfare losses in the labour market mostly arise from the inefficient pairing of job offers and job seekers.

Table 7. Welfare losses of homeownership tax policy

In billion EUR, 2006

\begin{tabular}{lc}
\hline Direct welfare losses of biased tenure choice & 1.2 \\
Decrease in housing costs & 0.5 \\
Regulatory tax (transfer tax) & 0.7 \\
Welfare losses on labour market & 0.3 \\
Inefficient consumption package & 0.1 \\
Inefficient pairing on housing market & 0.0 \\
Inefficient pairing on labour market & 0.3 \\
Productivity & 0.2 \\
Labour participation & 0.0 \\
Agglomeration advantages & n. a. \\
Rent-buy decision / portfolio composition ${ }^{1}$ & n. a. \\
Total & 1.5 \\
\hline
\end{tabular}

n. a.: not available.

1. Depends on subsidisation of renting versus owning; effects unknown.

Source: Besseling P., L. Bovenberg, G. Romijn and W. Vermeulen (2008; based on Koning et al. 2006).

To promote greater housing mobility, the tax system should be rebalanced by reducing the taxation of property purchase and increasing the taxation of ownership of real assets. In addition, taxation of ownership should aim at securing tax neutrality vis-à-vis other assets. If the aim is to maximise mobility, 
the transfer tax should be abolished or at least lowered. To avoid the reduction in transaction taxes being capitalised into higher house prices, it is important that such reform is accompanied by measures to boost the flexibility of housing supply, notably by reforming land use regulation. This measure should be accompanied by at least a similar reduction in the income tax subsidy to owner-occupied housing to ensure budget neutrality. Overall, the tax treatment of homeowners should follow the tax treatment of investors in real estate and financial assets (OECD, 2004; Stevens, 2005). Concerning the special savings accounts for mortgage repayment, all savings should be taxed in a similar way. The reduction in income tax subsidies could be achieved by increasing the taxation of imputed rent (while applying it to all owner-occupied dwellings). In case such a reform cannot be achieved, an increase in property taxes or a reduction or abolition of mortgage interest deduction should be considered.

\section{The regulation of the rental sector should be eased}

The rental sector consists of a large concentrated social (non-profit) housing part with more than 400 large social housing organisations (Annex A1) and a smaller private (commercial) part (Centraal Fonds Volkshuisvesting, 2009; Haffner et al. 2009a). The latter is fragmented among several hundred thousand landlords, typically individuals who usually own a few older dwellings, but also some large scale institutional investors with newer stock, although these are leaving the private rental market because of the strict rent regulation (see below) and the politics of rent regulation that increases the uncertainty of returns. Despite the different focus of the private and social rental sectors, the policy instruments are largely the same: housing allowances (see Box 4), rent regulation and indefinite rental contracts.

\section{Box 4. Housing allowances provide for targeted affordability in rented housing}

Housing allowances are a relatively widely used policy instrument in the EU (in place in 14 other EU countries). One of the main advantages of this instrument is that it does not directly hamper labour-market mobility, as tenants can get housing allowances for any rental dwelling as long as the household and the dwelling fulfil the income and wealth requirements. Moreover, there is little empirical evidence that housing allowances by themselves create employment or income traps (Sociaal en Cultureel Planbureau, 2001 and 2005).

Any low-income tenant is in principle eligible for housing allowances and in 2006 the target group comprised about $44 \%$ of all tenants, although only one in three tenants actually receives the allowance. The average monthly housing allowance per recipient household was EUR 144, which constitutes more than one third of the average monthly rent of all tenants (WoON 2006, calculated by TU Delft).

The system of housing allowances is complex, depending on income, rent, age and composition of the household. Everyone has to pay a 'basic rent' which is income-dependent. Households are classified into four types according to whether they are single or multi-person and whether they are younger or older than 65 years. For each type of household a minimum income and a maximum income are given. Below the minimum income one receives the maximum subsidy; above the maximum income no subsidy is available. Between the minimum and maximum income the subsidy diminishes with marginal effective tax rates of between $21 \%$ and $38 \%$. Beyond a certain rent level the share of rent subsidised goes to $75 \%, 50 \%$ and $0 \%$ depending on household composition and age.

Housing allowances are an open-ended system; everyone who needs and applies for help will receive it. However, housing allowances cannot be considered a fully secure subsidy for tenants, as they are reduced when the housing allowance budget comes under pressure. Such a reduction comes about because Dutch ministries operate under medium-term spending targets fixed in the government's coalition agreement, meaning that unexpected financial setbacks on the spending side must be offset within the ministries' own budgets (OECD, 2008). This rule regularly puts the ministry responsible for housing under considerable pressure as expenditure on housing allowances rises during economic downturns. As a result, rent regulation has also become a budget policy instrument in the sense that not allowing rents to increase aids in controlling the rise in housing allowances.

\section{Strict rent regulation does not differentiate between social and private renting}

Rent regulation is in place in the Netherlands, as in many European countries. The resulting delinking of rents from housing market conditions is most likely to have induced the long run decrease of the share of the private rental sector all over Europe (ECB, 2003). The Netherlands is no exception. Rent regulation was introduced in the aftermath of World War II to protect tenants against rent increases 
(Elsinga et al., 2006). Nowadays, however, 95\% of the Dutch (social and private) rental market operates under rent regulation (henceforth referred to as the regulated rental sector, of which $85 \%$ belongs to social landlords and only $15 \%$ to private landlords). ${ }^{9}$ Moreover, indefinite security of tenure is applicable in both the social and private rented sector, although in the private sector short-term tenancy agreements of one year or longer are sometimes allowed (Haffner et al., 2009b; Haffner et al., 2008).

Rent regulation has two elements. A maximum rent level is applied to both existing and newly-built dwellings. It is based on the quality of the dwelling as stipulated in the so-called dwelling valuation system. This system awards points to a dwelling on the basis of the quality of the housing (on objectively quantifiable characteristics such as surface area and facilities) and the housing environment. The latter is determined by rent committees which tend to focus on the accessibility of amenities (shops, public transport, schools etc). In fact, however, the location is scarcely taken into account in the points system, although it is often the main free-market determinant of the price of real estate. The other instrument of rent regulation is a maximum rent increase which is set every year by central government (based on a decision by parliament) and which applies to all regulated rented dwellings. ${ }^{10}$ The government has decided to pursue an inflation-indexed rent policy in the period 2007-10 (OECD, 2009), implying a falling rent share of income over this period. This agreement led to the withdrawal of the proposal (which had gone to Parliament) to deregulate $25 \%$ of rental dwellings.

Dutch rental regulation differs from that in other European countries. Firstly, almost the same rules of rent regulation are applied in the social and private rental sector. This is usually not the case in other countries (Table 8). Another consequence of the Dutch system is that it allows rent differentials among comparable social dwellings, even in the same building. These arise whenever a new tenant moves in and rents are set higher than for the existing tenants. This contrast with the view that in social housing, for horizontal equity reasons households with similar income levels should pay similar rents for same quality dwellings. This practice does, however, allow some rent adjustment. Secondly, rent control applies to almost all rental dwellings. As a result, the price mechanism is switched off with long waiting lists (queuing) and illegal subletting of rental dwellings is taking place (particularly an issue in Amsterdam; OECD, 2009). In contrast, other countries have mostly based rents for new rent contracts/tenants on housing market conditions. Finally, the annual rent adjustment is a political decision in the Netherlands, while other countries either use a price index or reference rents of comparable dwellings.

Social landlords keep rents well below the maximum rent level, leading to a situation where they are crowding out private landlords, even in the higher-quality end of the market. ${ }^{11,12}$ The lower rents in social housing reflect not greater efficiency in housing provision, but subsidies (see below). The social landlords work with so-called target rents, which are expressed as a percentage of the maximum rent. As a result, the

9. The deregulated rental sector contains about five percent of the rented housing stock and consists of tenancy agreements concluded after 1 July of 1994 (1 July of 1989 for new built dwellings) and with a rent level that exceeded the so-called deregulation limit up to that date (Haffner et al., 2009a). The deregulation limit is equal to the maximum rent level applicable for housing allowances.

10. One part of the rent regulation distinguishes between social and private land lords, which is relevant when rent increases above inflation are allowed. Then, a maximum permissible total annual rent increase is only set for the social sector.

11. The average rent in the social sector is $69 \%$ of the maximum rent level in 2008, while in the private sector it is 83\% (Directoraat Generaal Wonen, Wijken en Integratie, 2008)

12. The umbrella organisation of institutional property investors, the IVBN, has submitted a complaint to the European Commission concerning the Dutch government's policy on social landlords. They argue that social landlords use state support for letting 'high-end' housing with relatively low rents to households are outside their target group (Priemus, 2008). 
social landlords are able to keep about 765000 dwellings (the difference between the two columns in row 4 of Table 9) in the regulated sector - dwellings that according to the point system should belong to the deregulated rental sector.

Table 8. Rent regulation in seven European countries (length of tenancy contract) ${ }^{1}$

\begin{tabular}{|c|c|c|c|}
\hline & Cost-price regulation & Market rent regulation & No regulation \\
\hline New contract & $\begin{array}{l}\text { Netherlands }{ }^{2} \text { : regulated stock } \\
\text { Sweden }^{3}\end{array}$ & France: sitting tenant & $\begin{array}{l}\text { Belgium }{ }^{4} \\
\text { United Kingdom }^{5} \\
\text { Germany } \\
\text { Spain } \\
\text { France: new tenant } \\
\text { Netherlands: non-regulated stock }\end{array}$ \\
\hline $\begin{array}{l}\text { Existing } \\
\text { contract }\end{array}$ & $\begin{array}{l}\text { Belgium (9 years is standard) } \\
\text { Spain ( } 5 \text { years) } \\
\text { France ( } 3-6 \text { years) } \\
\text { Netherlands }{ }^{2} \text { : regulated stock } \\
\text { (mostly permanent) } \\
\text { Sweden }^{3} \text { (permanent) }\end{array}$ & Germany (permanent) & $\begin{array}{l}\text { United Kingdom }{ }^{5} \text { ( } 6 \text { months) } \\
\text { Netherlands: non-regulated stock } \\
\text { (permanent or shorter) }\end{array}$ \\
\hline
\end{tabular}

1. There appears to be no clear correlation between tenure protection (length of contract) and rent regulation.

2 Rent adjustment is a political decision based on inflation (1.1\% in 2007) plus a certain percentage (that was set at 0 in 2007 ); rent level depends on quality norms.

3. Rent is based on costs, but negotiated between tenant unions and municipal housing companies.

4. Market rents for new contracts unless short-term contract changes into a standard contract of nine years.

5. Possible indirect rent regulation via local reference rents for housing allowance recipients in the private rental sector.

6. Separate legislation on exploitative rent setting. No written information has been found on this option for other countries, but it is not unlikely that other countries have general legislation against exploitation as well.

Source: Haffner et al. $(2008,2009 a, b)$.

Table 9. Number of social rental dwellings per rent level as expressed by extent of possible subsidisation via rent allowances

2006

\begin{tabular}{lcc}
\hline $\begin{array}{c}\text { Percentage of the rent covered by } \\
\text { housing allowances within the set } \\
\text { limits }\end{array}$ & $\begin{array}{c}\text { Dwellings and different segments } \\
\text { distributed according to actual } \\
\text { rent charged by social landlords }\end{array}$ & $\begin{array}{c}\text { Dwellings and different segments } \\
\text { distributed according to } \\
\text { maximum rents based on points }\end{array}$ \\
\hline Possible subsidy of $100 \%$ & 620000 & 109000 \\
Possible subsidy of $75 \%$ & 1400000 & 613000 \\
Possible subsidy of 50\% or 0\% & 312000 & 814000 \\
No subsidy (deregulation limit) & 75000 & 840000 \\
Total number of dwellings & 2400000 & 2400000 \\
\hline
\end{tabular}

1. Percentage of the rent covered by housing allowance within the set limits: between the share of the rent that a household has to pay and the next limit $100 \%$ of rent is subsidised; between that limit and the next limit $75 \%$ of rent is subsidised; between that limit and the next limit either 50\% (elderly; and single households) or $0 \%$ (other households) is subsidised; deregulation limit is maximum rent above which no housing allowances are available. At the same time this rent limit is the limit for dwellings for which rents are regulated. About 1 million households actually receive housing allowances.

Source: Van Blokland (2009). 


\section{The substantial subsidisation of rental housing leads to large welfare losses}

Social housing benefits from investment (so-called brick-and-mortar) subsidies effectively still in place. ${ }^{13}$ This is partly the direct result of the financial independence of social landlords from government in 1995, which gave them a dowry in the form of the present value of the future subsidies. Social landlords have to use this lump-sum subsidy as a revolving fund for which a rate of return lower than the market would accept. Moreover, the social housing associations receive an indirect subsidy in the form of lower land prices, sometimes offered in exchange for the provision of other infrastructure, such as playgrounds, pools, etc. Another form of an indirect subsidy is the government guarantee for the Guarantee Fund for Social Housing (known in Dutch as the WSW) - a private fund established by the social landlords in 1983. A social landlord pays a relatively low interest rate when a loan is guaranteed by the Guarantee Fund. The financial soundness of the sector and the government safety-net contribute to the triple-A investment status of the WSW and thus enables social landlords to take out low-interest loans for social housing objectives, providing for cheaper financing than for private investors.

The sum of the direct and indirect subsidies leads to a first-order effect in the form of a reduction of estimated market rents by almost $50 \%$ (excluding the effect of property tax) (Table 10). ${ }^{14}$ The annual cost of providing these subsidies has been estimated at EUR 14.5 billion (2.7\% of GDP). Assuming that the property tax effect would be similar to that for homeownership (EUR 500 in Table 4.6), then on average a tenant would receive more than EUR 4000 (4 750 in Table 4.1 less the 500 arising from the before mentioned property tax effect) in total subsidy. More than half of this comes from rent regulation, one third from rents below the maximum rent, and the rest from housing allowances. The targeting of these subsidies is poor as only a little less than half of this amount is received by low income households - the target group for housing allowances - although this group does enjoy a lowering of average rents by $56 \% .{ }^{15}$

Table 10. Implicit and explicit subsidies for tenants

\begin{tabular}{lrrr}
\multicolumn{1}{c}{2006} & & \\
\hline Type of subsidy & Total in EUR billion & $\begin{array}{c}\text { Average per } \\
\text { household (EUR) }\end{array}$ & $\begin{array}{c}\text { Average per household } \\
\text { (percentage of housing } \\
\text { costs) }^{1}\end{array}$ \\
\hline Rent regulation & 8.00 & 2750 & $26 \%$ \\
Lower rents by social landlords & 4.50 & 1500 & $15 \%$ \\
Housing allowances & 1.75 & 500 & $7 \%$ \\
Total & 14.25 & 4750 & $49 \%$ \\
\hline
\end{tabular}

1. Expressed as market rent.

2. It is not known whether tenants pay property tax via their rent, as the points system does not have points for property taxes.

Source: Besseling et al. (2008; based on Romijn and Besseling, 2008).

13. Tenants in social housing may at times also enjoy rents below costs (so-called unprofitable investment). This applies when the rents of new social dwellings do not cover the operational costs for the first few decades of operation. The unprofitable part of this investment in rent dwellings was on average $28 \%$ of the capital costs with average capital costs of a dwelling (including land costs) being EUR 147000.

14. Conijn (2008) argues that the calculations of Romijn and Besseling (2008) should not take into account the market value of an unoccupied dwelling in the case of a rental dwelling, but of a dwelling which excludes the tax effect on homeownership. The subsidy as share of market rent is estimated on average to be $41 \%$ rather than $50 \%$. In his own calculations based on the value gap between the market value of a dwelling and the market value of a social dwelling rented out, it can be concluded that the rent subsidy must be $37 \%$.

15. Three quarters of the subsidy is distributed by social landlords implying a rent deduction of $50 \%$ for their tenants in comparison to estimated market rents, again raising the issue of poor targeting. 
The subsidisation of (social) rents leads to estimated welfare losses of at least EUR 5 billion per year (1\% of GDP) (Table 11) under the assumption of a relatively elastic long-term supply. ${ }^{16}$ More than $80 \%$ of this is attributed to the direct effects of tenure choice being biased towards (social) rentals. The rest of the welfare loss is estimated to arise on the labour market as a result of distorted consumption decisions and inefficient matching on the housing and labour markets. The social costs of the policy are estimated to outweigh the gains by an average of EUR 900 per rental unit per year, reflecting the fact that middle and high income households live in dwellings they actually find too small and low-income households live in dwellings which on average are too big (Romijn and Besseling, 2008).

Table 11. Welfare losses of rent policies

in billion EUR

\begin{tabular}{|c|c|}
\hline & 2006 \\
\hline Direct welfare losses of biased tenure choice, & 3.9 \\
\hline $\begin{array}{l}\text { Decrease in housing costs } \\
\text { Regulatory tax (rent regulation) }{ }^{1}\end{array}$ & $\begin{array}{l}2.5 \\
1.4\end{array}$ \\
\hline Labour market & 0.9 \\
\hline Inefficient consumption package & 0.3 \\
\hline Inefficient pairing on housing market & 0.1 \\
\hline Inefficient pairing on labour market & 0.5 \\
\hline $\begin{array}{l}\text { Productivity } \\
\text { Labour participation } \\
\text { Agalomeration advantages }\end{array}$ & $\begin{array}{l}0.4 \\
0.1 \\
0.9\end{array}$ \\
\hline Rent-buy decision / portfolio composition ${ }^{2}$ & n. a. \\
\hline Total & 4.8 \\
\hline
\end{tabular}

n. a.: not available.

1. Based on the small policy target group, the households that are eligible for rent allowances.

2. Depends on subsidisation of renting versus owning; effects unknown.

Source: Besseling et al. (2008; based on Romijn and Besseling, 2008).

\section{A larger role for the deregulated rental sector to improve labour mobility}

Rent regulation is the main factor responsible for the inability of the rental sector to provide geographical flexibility of labour, because of the lock-in effects of the relatively large value of discounted future subsidies provided by below-market rents. Thus, reform should aim at addressing this insider issue. Liberalisation does not necessarily imply that there needs to be a large extension of the rental sector. However, there is a need to increase the part of the rental sector with free rent setting. This implies that the social housing associations should focus on their core expertise of providing affordable housing for low-income and other targeted households. In this respect, a system has to be established to prevent the leakage of rent control subsidies to higher-income households, implying increased use of means testing. As a consequence of the need for housing associations to focus on their core activities, the part of the social housing sector that is currently providing social housing to tenants that are no longer eligible for such services should be sold off. This can either be through the sale of housing blocks to private investors (which could include spin-offs from the social housing associations themselves) or to tenants.

16. The subsidy would amount to at least two billion EUR (0.4\% of GDP), if the price elasticity of supply is assumed to be zero. Also if calculations were based on policy group for social renting instead of policy group for housing allowances the costs will be lower. 
Attracting new investors to the private rental sector requires that rents be liberalised to generate competitive rates of return vis-à-vis other investment opportunities. Rent liberalisation should be phased in to avoid disruptive rent developments. As a first measure, investors should be allowed to freely set rents in new construction. Secondly, rents for new contracts for existing dwellings should be deregulated. This should be phased in by allowing that new rents are set by a formula that takes into account the previous rent plus a part of the difference between existing rents and market based rents. Subsequently, to remove political uncertainties, rents should be indexed to a pre-determined index that reflects the cost of housing for example construction costs. To reduce rent differentials between new and existing contracts, the rent regulation of the latter should follow the same indexation as for new contracts plus a catch-up factor that allow rents to converge within a reasonable time span. In addition, contracts should no longer be indefinite, but subject to periodic renegotiations, strengthening the position of tenants as rents approach market-based levels, particularly during economic downswings. There is also a need for allowing private landlords to enter the middle segment of the rental market. This can be achieved by lowering the maximum rent of the social dwellings with the maximum number of points (limit for deregulated rent). This could be done discretely or by (temporarily) suspending indexation.

Deregulating rents for existing social tenants should focus on those cases where household income has increased to above the threshold for social housing. A number of options exist to normalise the situation for such high-income households. As rent normalisation implies market-based rents, previously regulated rents for high income households should increase faster than regulated rents. This can be achieved in a number of ways: for example, rents could be increased at a fixed rate above that of regulated rents or they could become a function of the tenants' incomes, so that completely deregulated rents would only apply to households with incomes above a certain level. The drawback of the latter solution is the associated bureaucracy and the removal of the link between dwellings' rent levels and their quality. A less bureaucratic solution is to allow tenants who are no longer considered to be eligible for social housing to purchase their dwelling from the housing association. The government cannot force social housing associations to sell, but would have to rely on persuasion. This could for example be in the form of taxing the additional rent income higher than the capital gains associated with sale to tenants. At the same time, it should be remembered that, although the social housing associations are private entities, their capital has been built up over time through large direct and indirect subsidies from the government. Thus, excessive capital gains arising from free rent setting or sale of dwellings should be transferred to the government.

The provision of social housing should be more closely related to employment opportunities; at least until a fully functioning deregulated private rental market has been established. Thus, in order to underpin labour market mobility, the allocation of social rental dwellings should give priority to households that seek housing for employment related reasons. Moreover, the provision of social housing should not only be the prerogative of social housing associations. As rents become increasingly market based, social objectives should be increasingly pursued through housing allowances, which have the added benefit of being less mobility distorting than rent control. Such a measure would also give the government more direct control in securing heterogeneous neighbourhoods. To enhance the transparency with respect to the benefits of the social housing associations' provision of non-housing services to boost living qualities within neighbourhoods, such as urban renewal, a framework should be established to evaluate the costs and benefits of such services and the social housing associations should be compensated directly for the associated costs.

Liberalising rents while maintaining strict supply-side regulation will only lead to large rent increases. These will be capitalised into higher property prices, leading to large windfall gains for landlords without securing much more flexibility. Consequently, measures to secure a supply response are needed, preferably even before an announced deregulation of rents to secure a supply effect through expectations. This would point to the above proposed reconsideration of the strict land use policy as well as to the importance of securing new entrants into the liberalised rental segment. Given the already high household spending on 
housing, a flexible supply side should secure that, at the overall level, there will not be much change in rents and house prices. Nevertheless, in a more liberalised housing market some landlords are likely to enjoy substantial windfall capital gains, which only reflect changes in the long-standing rent regulation, and should thus be transferred to the government.

Box 5. Recommendations to increase the flexibility in the housing market to enhance labour mobility

\section{Land use policies should be adjusted to facilitate a more responsive supply side}

- $\quad$ Land use should be evaluated with respect to economic and labour market policies as well as for creating living space to facilitate the weighing of policy options. In particular, zoning laws should be reviewed to secure the development of housing and recreational areas, such as new forest and nature parks, in the Green Heart.

- $\quad$ Planning needs to be supplemented by creating incentives for local municipalities to develop housing. For example, they should be allowed to benefit in terms of greater (property) net tax revenues.

In the owner-occupied sector:

- To achieve a greater degree of tax neutrality, all actual income from financial assets and all imputed income (based on market rates) should be taxed at the same rate and all costs involved in producing that income should be deductible at the same tax rate. Neutrality between mortgage financing and savings should be pursued by replacing the tax deductibility of mortgage interest payments with the principle of taxing net housing value, i.e. deducting the value of the mortgage loan from the value of the house.

- The transfer tax should be abolished (or lowered) and should be accompanied by measures to boost the flexibility of housing supply to avoid higher house prices. At least a similar reduction in the income tax subsidy to owner-occupied housing is required to ensure budget neutrality.

- The income tax subsidies should be reduced by increasing the taxation (and its scope) of imputed rent. Alternatively, higher property taxes or reducing the value of or abolishing the mortgage interest deduction should be considered, although this would exclude tax neutrality.

In the rental sector:

To increase the part of the rental sector with free rent setting:

- The social housing associations should focus on their core activity of providing affordable housing for low-income and other targeted type of households. The part of the social housing sector that is providing social housing to non-eligible tenants should be sold off, either through the sale of housing blocks to private investors or to tenants.

\section{To phase in rent liberalisation:}

- $\quad$ Rents should be freely set in new constructions. Rents for new contracts for existing dwellings should be gradually deregulated by allowing new rents to be set as the previous rent plus a part of the difference between existing and market based rents. Market based rents should be indexed to a pre-determined index that reflects the cost of housing so as to remove political uncertainties and rental contracts should no longer be indefinite.

To reduce rent differentials between new and existing contracts

- Rent regulation of existing contracts should follow the same indexation as for new contracts plus a catch-up factor to ensure convergence. Moreover, contracts should no longer by indefinite to strengthen the position of tenants as rents approach market-based levels.

- To allow private landlords to enter the middle segment of the rental market, the maximum rent of social dwellings should be (gradually) lowered. 


\section{To deregulate rents for social tenants}

- To prevent the leakage of rent control subsidies to higher-income households, means testing should be extended to sitting tenants.

- Normalising rents for higher-income households in social housing implies that their previously regulated rents should increase faster than regulated rents, by for example increasing them at a fixed rate above that of regulated rents or making them a function of the tenants' incomes.

- A less bureaucratic solution is to allow high income tenants in social housing to purchase their dwelling. The housing associations should be given incentives to do so, by for example raising taxation of additional rent income. At the same time, excessive capital gains arising from free rent setting or sale of dwellings should be transferred to the government.

- Until a fully functioning private rental market is operational, labour market mobility should be supported by giving priority in social housing to households with employment related reasons.

- The provision of social housing should not only be the prerogative of social housing associations and social objectives should be increasingly pursued through housing allowances.

- A framework should be established to evaluate the cost and benefits of social housing associations' provision of non-housing services to boost living qualities within neighbourhoods and the associations should be compensated directly for the associated costs.

\section{Bibliography}

AFSW (2007), Jaarboek 2007, Amsterdam.

André, C. (2009), A Bird’s Eye View of OECD Housing Markets, paper presented at ECB Workshop on the Housing Market and the Macroeconomy, Frankfurt am Main, 26-27 November.

Barr, N. (1998), The Economics of the Welfare State, Oxford: Oxford University Press, $3{ }^{\text {rd }}$ edition.

Battu, H., A. Ma and E. Phimister (2009), Housing Tenure, Job Mobility, and Unemployment in the UK, in: in: Van Ewijk, Casper and Michiel Van Leuvensteijn (eds.) Homeownership and the Labour Market in Europe, Oxford, Oxford University Press, pp. 161-183.

Besseling, P., L. Bovenberg, G. Romijn and W. Vermeulen (2008), De Nederlandse woningmarket en overheidsbeleid: over aanbodrestricties en vraagsubsidies, in: F.J.H. Don, Agenda voor de woningmarkt, Amsterdam, Koninklijke Vereniging voor de Staatshuishoudkunde, pp. 13-77.

van Blokland, F. (2009), Wat zijn sociale en wat zijn commerciële huurwoningen? Tijdschrift voor de Volkshuisvesting, nr. 1, pp. 18-21.

CBS (2007), Forse stijging opgeleverde woningen, press release of 25 March.

Centraal Fonds Volkshuisvesting (2008), Sectorbeeld realisaties woningcorporaties, verslagjaar 2007, Naarden.

Centraal Fonds Volkshuisvesting (2009), Trends in the corporatiesector 2004-2008, Naarden. 
Conijn, J. (2008), Subsidiëring van de woonconsumptie: een zinloos schip van bijleg, in: F.J.H. Don, Agenda voor de woningmarkt: inleiding, in: F.J.H. Don, Agenda voor de woningmarkt, Amsterdam, Koninklijke Vereniging voor de Staatshuishoudkunde, pp. 145-177.

Coulson, N. E. and L. M. Fisher (2009), Housing tenure and labour market impacts: the search goes on, Journal of Urban Economics, 65(3), pp. 252-264.

Czischke, D. and Pittini A. (2007), Housing Europe 2007: Review of Social, Co-operative and Public Housing in the 27 EU Member States, CECODHAS European Social Housing Observatory.

van Daalen, G. and M. van der Land (2008), Next Steps in Choice-based Letting in the Dutch Social Housing Sector, European Journal of Housing Policy 8 (3), pp. 317-328.

De Graaff, T. and M. van Leuvensteijn (2007), The impact of housing market institutions on labour mobility. A European cross-country comparison, Bureau for Economic Policy Analysis.

De Graaff, T., M. van Leuvensteijn and C. van Ewijk (2009), Homeownership, Social Renting, and Labour Mobility across Europe. Oxford, Oxford University Press, pp. 53-81.

Directoraat-Gerneraal Wonen, Wijken en Integratie (2008), Feiten en achtergronden van het huurbeleid 2008, Arnhem, Companen.

Dohmen, Thomas J. (2009), Housing, Mobility, and Unemployment, in: Van Ewijk, Casper and Michiel Van Leuvensteijn (eds.), Homeownership and the Labour Market in Europe, Oxford, Oxford University Press, pp. 15-41.

ECB (2003), Structural Factors in the EU Housing Market, Frankfurt am Main, European Central Bank.

ECB (2009), Housing Statistics in the European Union 2005/2006.

Eichholtz, P and Lindenthal, T. (2008), Behoeftes en belemmeringen in de woningbouw: een lange termijn perspectief. In: "Agenda voor de woningmarkt". Don, F.J.H. (eds). Amsterdam: Koninklijke Vereniging voor de Staatshuishoudkunde.

Elsinga, M., M.E.A. Haffner and H.M.H. van der Heijden (2006), Nederlandse woondiscussies in international perspectief, in: Kraan, D.J. and C. Lever (eds.) In Holland staat een huis. Het volkshuisvestingsbeleid op een kruispunt, Den Haag.

European Foundation for the Improvement of Living and Working Conditions (2005), Mobility in Europe. Analysis of the 2005 Eurobarometer survey on geographical and labour market mobility, Dublin, European Foundation for the Improvement of Living and Working Conditions.

van Ewijk, C. and M. Van Leuvensteijn (2009) (eds.), Homeownership and the Labour Market in Europe, Oxford, Oxford University Press.

van Ewijk, C., M. Koning, M. Lever and R. de Mooij (2006), Economische effecten van aanpassing fiscale behandeling eigen woning, Den Haag, Centraal Planbureau.

Flatau, P., M. Forbes, P.H. Hendershott and G. Wood (2003), Homeownership and unemployment: the roles of leverage and public housing, NBER Working Paper 10021. 
Green, R. and P. Hendershott (2001), Home-ownership and unemployment in the US, Urban Studies, 38(9), pp. 1509-1520.

Green, R. and P. Hendershott (2002), Homeownership and the duration of unemployment: a test of the Oswald hypothesis’, paper presented at AREUEA Annual Meetings, January.

Haffner, M., M. Elsinga and J. Hoekstra (2008), Rent Regulation: The Balance between Private Landlords and Tenants in Six European Countries, European Journal of Housing Policy, 8, No. 2, pp. 217-233.

Haffner, M., J. Hoekstra, M. Oxley and H. van der Heijden (2009a), Bridging the gap between market and social rented housing in six European countries, Amsterdam, IOS Press BV.

Haffner, M., M. Elsinga and J. Hoekstra (2009b), Huurregulering vanuit de welvaartseconomie ontleed, Tijdschrift voor de Volkshuisvesting, 15, nr. 1, pp. 43-48.

van Hoek, T. (2009), Hervorming van de woningmarkt, Amsterdam, Economisch Instituut voor de Bouw.

Høj, J. V. Galasso, G. Nicoletti and T.-T. Dang (2006), The political economy of structural reform: Empirical evidence from OECD countries, Economics Department Working Papers No. 501.

Koning, M., R. S. Nistal and J. Ebregt (2006), Woningmarkteffecten van aanpassing fiscale behandeling eigen woning, Den Haag, Centraal Planbureau.

van Leuvensteijn, M. and P. Koning (2000), The effects of Home-ownership on Labour Mobility in The Netherlands: Oswald's theses revisited, CPB Netherlands Bureau for Economic Policy Analysis.

van Leuvensteijn, M. and P. Koning (2009), The effect of homeownership on Labour Mobility in the Netherlands, in: Van Ewijk, Casper and Michiel Van Leuvensteijn (2009).

Lundborg, P. and P. Skedinger (1999), Transaction Taxes in a Search Model of the Housing Market, Journal of Urban Economics, 45, pp. 385-399.

Ministerie van VROM (2004), Cijfers over Wonen, Den Haag, MVROM.

Ministerie van VROM (2005), Rijksbegroting 2006, begroting XI Volkshuisvesting Ruimtelijke Ordening en Milieubeheer, Den Haag, Sdu.

Ministeries van VROM, LNV, VenW en EZ (2004), Nota Ruimte: Ruimte voor Ontwikkeling.

Ministerie van VROM (2009), Van der Laan: 'Overeenstemming over staatssteunregeling voor corporaties', press release of 8 October.

Munch, J.R. and M. Svarer (2002), Rent control and tenancy duration, Journal of Urban Economics, 52.

Munch, J. R., M. Rosholm and M. Svarer (2009), Homeownership, Job Duration, and Wages, in Van Ewijk, C. and M. Van Leuvensteijn (2009).

OECD (2004), Economic Survey of the Netherlands, 2004, Paris.

OECD (2007), Territorial Reviews: Randstad Holland; Paris.

OECD (2008), Economic Survey of the Netherlands, Paris. 
van Ommeren, J. (2006), Verhuismobiliteit: een literatuurstudie naar belemmeringen tot verhuizen, opdracht van het ministerie van VROM, december.

van Ommeren, J. and M. van Leuvensteijn (2003), New evidence of the effect of transaction costs on residential mobility, CPB Discussion Paper No 18, May.

van Ommeren, J.N. and M. van Leuvensteijn (2005), New evidence of the effect of transaction costs on residential mobility, Journal of Regional Science, pp. 681-702.

van Oort, F., T. De Graaff, G. Renes and M. Thissen (2008), Economische dynamiek en de Randstedelijke woningmarkt, in: F.J.H. Don, Agenda voor de woningmarkt: inleiding, in: F.J.H. Don, Agenda voor de woningmarkt, Amsterdam, Koninklijke Vereniging voor de Staatshuishoudkunde, pp. 101-124.

Oswald, A. J. (1996), A conjecture on the explanation for high unemployment in the industrialized nations: Part I, Warwick Economic Research Paper 475.

Oswald, A. J. (1997), Theory of homes and jobs, mimeo, University of Warwick.

Oswald, A. J. (1999), The housing market and Europe's unemployment: a non-technical paper, mimeo, University of Warwick.

O’Sullivan, A, T.A. Sedon and S.M. Sheffin (1995), Property taxes, mobility, and homeownership, Journal of Urban Economics, 52(3), pp. 542-560.

Partridge, M. and D. Rickman (1997), The dispersion of US state unemployment rates: the role of market and nonmarket equilibrium factors, Regional Studies, 31, pp. 593-606.

Pehkohnen, J. (1999), Unemployment and home-ownership, Applied Economics Letters, 6, pp. 263-265.

Priemus, H. (2008), Real Estate Investors and Housing Associations: A Level Playing Field? The Dutch Case, European Journal of Housing Policy, 8(1), pp. 81-96.

Rouwendal, J. and J. van Ommeren (2006), Verhuismobiliteit: de overdrachtsbelasting en huurprijsregulering onder de loep genomen, TPE, 27(6), pp. 76-93.

RIGO Research en Advies BV (2007), Wonen op een rijtje. De resultaten van het Woononderzoek Nederland 2006, Den Haag, Ministerie van VROM.

Romijn, G., and P. Besseling (2008), Economische effecten van regulering en subsidiering van de huurwoningmarkt, Den Haag, Centraal Planbureau.

Sociaal en Cultureel Planbureau (2001), Armoedemonitor 2001, Den Haag.

Sociaal en Cultureel Planbureau (2005), Armoedemonitor 2005, Den Haag.

Stevens, L.G.M. (2005), Naar een nieuw eigenwoningregime, ESB, 90(4455), pp. 100-102.

Svarer, M., M. Rosholm, and J.R. Munch (2005), Rent control and unemployment duration, Journal of Public Economics, 89, pp. 2165-2181.

Swank, J., J. Kakes and A Tieman (2002), The Housing Ladder, Taxation and Borrowing Constraints, Amsterdam, De Nederlandsche Bank. 
Teulings, C.N., A.L. Bovenberg and H.P. van Dalen (2003), De Calculus van het publieke belang, Den Haag, Kenniscentrum voor Ordeningsvraagstukken.

Tompson (2009), Advancing Structural Reforms in OECD Countries: lessons from 20 Case Studies, Annex 6: Draft Case Studies -Netherlands, Paris.

Tweede Kamerfracties van CDA, PvdA en ChristenUnie (2007), Coalitieakkoord tussen de Tweede Kamerfracties van CDA, PvdA en ChristenUnie. Den Haag: Tweede Kamerfracties van CDA, PvdA en ChristenUnie, 7 februari.

Vermeulen, W. and J. van Ommeren (2006), Housing supply and the interaction of regional population and employment, CPB Discussion Paper, No. 65.

Vermeulen, W. and Rouwendal J. (2007), Housing supply in the Netherlands, The Hague, CPB Netherlands Bureau for Economic Policy Analysis.

van der Vlist, A.J. (2001), Residential Mobility and Commuting, Thela Thesis, Tinbergen Institute.

van Vuuren, A. (2009), The Impact of Homeownership on Unemployment in the Netherlands, in: Van Ewijk, Casper and Michiel Van Leuvensteijn (2009). 


\section{Social housing policies in the Netherlands: a historical perspective}

The large social rental sector is the outcome of continuous government intervention since the 1901 Housing Act (Haffner et al., 2009). Government intervention increased after 1945 as the already urgent housing shortage caused by World War II was aggravated by strong population growth and new family living arrangements. Housing policies became focused on the construction of dwellings, particularly through bricks-and-mortar subsidies. Moreover, with its spatial planning policy, the government exercised a strong influence on the location, quality and quantity of new-built dwellings. The housing shortage was to a large degree eased through an expansion of the social rented sector, which was regarded as more capable of realising construction projects than the market sector - and not unimportant under government supervision and management. Since the 1970s, housing policy has been targeted towards providing more of choice for households (including low-income households) between buying and renting, and by transforming the quality of both new buildings and the existing stock (urban renewal). A combined system of bricks-and-mortar subsidies and housing allowances was chosen. Bricks-and-mortar subsidies were designed to keep new social rented dwellings within reach of households with (below) average incomes, while housing allowances were to widen the choice for residents with a lower income. At the end of the 1970s the promotion of home-ownership and cuts in the subsidies for the social rented sector became important aspects of government policy - the share in the national budget decreased from almost $9 \%$ in 1985 to 3.1\% in 1995 (Sociaal en Cultureel Planbureau, 1998).

Housing policies changed tack with the 1989 publication of the policy document entitled 'Housing in the 1990s: from building to living' (Ministerie van VROM, 1989). The document made a case for a greater role of market forces on the housing market by reallocating responsibilities and financial risks among the players on the housing market and concentrating financial support on the low-income groups. An underlying goal was to control and reduce government spending on housing. Decentralisation was another element as housing was seen less as a task of central government and more of a task to be carried out at the provincial and municipal levels together with the relevant actors on the market. As a result, policies for the social rented sector became geared towards decentralisation, deregulation and (financial) independence, including securing their investment risk capacity and giving greater freedom in rent setting and asset management. The latter included expanding the possibilities for social landlords to sell social rented dwellings in order to raise capital for construction or improvements of dwellings. The status of the social landlords was not changed as they had originally been given a private legal status to keep them on arm's length from government. However, they became financial independent institutions with public task via a grossing and balancing operation in 1995. This operation removed the financial ties between the social landlords and the national government by the government paying off the net present value of its annual subsidy obligations to the social landlords (emanating from the long-term subsidy arrangements from before 1992) and the social landlords (mainly) reimbursed outstanding government loans by means of accelerated repayment. Essentially, this moved the operational risks from the government to the social landlords and the social landlords began to operate as revolving fund subsidising social rents themselves. In addition, bricks-and-mortar subsidies were abolished. 


\section{Box 4.A1.1. Dutch social landlords and the framework of policy and control}

In the social sector a little over 400 non-profit housing associations (also referred to as social landlords) are active (Centraal Fonds Volkshuisvesting, 2008). Non-profit in the sense of the Housing Act 1901's non-distribution constraint, which stipulates that any profits have be used for housing. Housing associations operate as foundations with a board of directors as the main decision makers - in contrast with the previous situation where the tenants as members were in power. Most of the housing associations are relatively large (and growing) with almost 60 housing associations owning more than 10000 dwellings and about 250 housing associations owning between 500 and 5000 dwellings. The average number of units per housing association differs according to urban (9 600) and nonurban (3 600) areas. The 2007 average market value of the housing associations' rental dwellings was estimated to be EUR 150000 , some two-thirds of the average market value of all dwellings. The total property value of the housing associations is estimated to amount to EUR 380 billion, close to $65 \%$ of GDP.

Since the grossing and balancing operation social landlords are required to work within the framework stipulated in the Social Housing Management Decree (1993), which is based on the Housing Act (1901). The Social Housing Management Decree (also known by its Dutch abbreviation, BBSH) stipulates six areas of performance for the housing associations which are accredited or registered institutions according to the Housing Act. The core mission is to provide housing for predominantly those who are unable to find an appropriate dwelling for themselves (the target group for social renting). Furthermore, they have to maintain a decent quality of the dwellings, to consult with the tenants, to be a financially sound organisation, to contribute to liveable neighbourhoods (added in 1997) and to provide housing (but not care) for the elderly and for handicapped people (added in 2001). In short, they are expected to operate as what is called 'social entrepreneurs'. This means that they are also allowed to generate income by market activities such as renting of dwellings to middle-income and higher-income groups and developing owner-occupier dwellings for sale. They are also allowed to construct so-called societal real estate (schools, neighbourhood centres, etc.; Ministerie van VROM, 2009). Housing associations thus should use their equity for housing, subsidising social rents as a revolving fund. Extra funds that can be used for lowering rents come out of sales of dwellings (Centraal Fonds Volkshuisvesting, 2009).

A main political concern is who owns the equity of the legally private organisations that have no shareholders to which the social landlords are accountable. Related to this are the questions about how well they fulfil their public tasks and the lack of strong supervision. The ultimate sanction for housing associations that perform poorly is the removal from the register. The implications of this sanction and the sum of money to be paid to the government in such cases are unclear as in reality the situation has never arisen. A response to these discussions was the addition of tasks in due course in the BBSH. Also the considerations have resulted in the introduction of corporate tax for the social landlords as of 1 January 2008 and the levy housing associations have to pay into a fund to be spent on tackling problems in the 40 problem neighbourhoods. The housing associations are to make performance agreements with local governments for the improvements of these neighbourhoods. In addition, the government is aiming to reach agreements with the social landlords on a contribution to investments in the energy efficiency of existing dwellings and increasing the number of new affordable homes.

Large amounts of money are automatically earmarked for the social tasks that housing associations are to fulfil as a revolving fund. There is little explicit decision making whether these funds should indeed be used for the aims to which they are directed. Moreover, the large gap between market value of a social rental dwelling (EUR 150000 in 2007) and the present day value of rents (EUR 34 000) raises the question of whether housing associations are the most efficient and effective way to house needy households (Centraal Fonds Volkshuisvesting, 2008).

\section{Bibliography}

Centraal Fonds Volkshuisvesting (2008), Sectorbeeld realisaties woningcorporaties, verslagjaar 2007, Naarden.

Centraal Fonds Volkshuisvesting (2009), Trends in the corporatiesector 2004-2008, Naarden.

Haffner, M., J. Hoekstra, M. Oxley and H. van der Heijden (2009), Bridging the gap between market and social rented housing in six European countries, Amsterdam, IOS Press BV.

Ministerie van VROM (1989), Volkshuisvesting in de jaren negentig: van bouwen naar wonen, MVROM.

Ministerie van VROM (2009), Van der Laan: 'Overeenstemming over staatssteunregeling voor corporaties', press release of 8 October.

Sociaal en Cultureel Planbureau (1998), Sociaal en Cultureel Rapport 1998. 25 jaar sociale verandering, Rijswijk. 
ECO/WKP(2011)2

\section{WORKING PAPERS}

The full series of Economics Department Working Papers can be consulted at www.oecd.org/eco/workingpapers/

832 Making the Dutch pension system less vulnerable to financial crises (January 2011) by Jens Høj

831 Real house prices in OECD countries: the role of demand shocks and structural policy factors

(December 2010) by Dan Andrews

830 International financial integration and the external positions of euro area countries (December 2010) by Philip R. Lane

829 Improving fiscal performance through fiscal councils (December 2010) by Robert Hagemann

828 Minimising risks from imbalances in European banking (December 2010) by Sebastian Barnes, Philip Lane and Artur Radziwill

827 Resolving and avoiding unsustainable imbalances (December 2010) by Sebastian Barnes

826 Current account imbalances in the euro area: a comparative perspective (December 2010) by Sebastian Barnes, Jeremy Lawson and Artur Radziwill

825. Does fiscal decentralisation strengthen social capital? Cross-country evidence and the experiences of Brazil and Indonesia (December 2010) by Luiz de Mello

824. Fiscal decentralisation and public investment: The experience of Latin America (December 2010) by Luiz de Mello

823. Product market regulation and competition in China (December 2010) by Paul Conway, Richard Herd, Thomas Chalaux, Ping He and Jianxun Yu

822. Reforming China's monetary policy framework to meet domestic objectives (December 2010) by Paul Conway, Richard Herd and Thomas Chalaux

821. Regulatory reforms to unlock long-term growth in Turkey (December 2010) by Rauf Gönenç and Łukasz Rawdanowicz

820. After the crisis: mitigating risks of macroeconomic instability in Turkey (December 2010) by Lukasz Rawdanowicz 
819. The 2008-09 crisis in Turkey: performance, policy responses and challenges for sustaining the recovery

(December 2010) by Łukasz Rawdanowicz

818. Fiscal-consolidation strategies for Canadian governments

(November 2010) by Yvan Guillemette

817. The land transport sector: policy and performance

(November 2010) by Jan Persson and Daeho Song

816. A simple model of the relationship between productivity, saving and the current account (November 2010) by Jean-Marc Fournier, Isabell Koske

815. The impact of structural policies on saving, investment and current accounts (November 2010) by Clovis Kerdrain, Isabell Koske, Isabelle Wanner

814. Towards a less distortive and more efficient tax system in Portugal (November 2010) by Alvaro Pina

813. Are global imbalances sustainable? Shedding further light on the causes of current account reversals

(November 2010) by Luiz de Mello, Pier Carlo Padoan, Linda Rousová

812. Turkey's improving integration with the global capital market: Impacts on risk premia and capital costs

(November 2010) by Rauf Gönenç, Saygin Şahinöz, Özge Tuncel

811. Trade linkages in the OECD trade system

(October 2010) by Jérôme Brézillon, Stéphanie Guichard and Dave Turner

810. Enhancing the effectiveness of social policies in Indonesia

(October 2010) by Margherita Comola and Luiz de Mello

809. Tackling the infrastructure challenge in Indonesia

(October 2010) by Mauro Pisu

808. Phasing out energy subsidies in Indonesia

(October 2010) by Annabelle Mourougane

807. Implementing cost-effective policies in the United States to mitigate climate change (October 2010) by David Carey

806. Restoring fiscal sustainability in the United States

(October 2010) by Patrick Lenain, Bob Hagemann and David Carey

805. Norway: Sustainable development: climate change and fisheries policies (September 2010) by Paul O’Brien

804. Netherlands: How the transport system can contribute to better economic and environmental outcomes

(September 2010) by Tomasz Koźluk 